\author{
Jurnal Pendidikan Dasar Indonesia is licensed under \\ A Creative Commons Attribution-Non Commercial 4.0 International License
}

\title{
Strategi Pendampingan Berkelanjutan sebagai Alternatif Peningkatan Kompetensi Guru dalam Penggunaan Media Pembelajaran Berbasis IT
}

\author{
Inna Dalilah \\ Sekolah Dasar Negeri 65 Singkawang \\ E-mail :inadalilah@yahoo.com
}

\begin{abstract}
Abstrak: SDN 65 Singkawang yang berada pada ranking terbawah hasil UASBN disebabkan karena guru mengajar masih menggunakan metode pembelajaran konvensional. Untuk mengkondisikan proses belajar mengajar yang bermutu, perlu peningkatan kompetensi guru dalam menggunakan media pembelajaran berbasis IT melalui bimbingan berkelanjutan, Maka diadakanlah IHT dalam bentuk Workshop SAGUSAMED dan Inovasi Pembelajaran. Setelah dilakukan supervisi didapatlah kesimpulan bahwa ada perubahan cara mengajar guru, Sebagian guru sudah mengajar menggunakan media pembelajaran berbasis IT.Guru juga sudah melakukan inovasi pembelajaran dengan menggunakan yel-yel atau mengubah materi pembelajaran dalam bentuk lagu agar mudah dipahami anak .Dampak dari semua ini adalah siswa berhasil menjadi juara I Lomba Olympiade Siswa Nasional Tingkat Kota dan peningkatan pada ranking sekolah
\end{abstract}

Kata Kunci: Kompetensi guru; Media Pembelajaran; Bimbingan Berkelanjutan.

\section{PENDAhuluan}

Berbagai penelitian menunjukkan bahwa fungsi manajerial dari seorang kepala sekolah memiliki pengaruh yang positif terhadap keseluruhan kegiatan sekolah dan administrasi sekolah, mulai dari suasana pembelajaran yang kondusif, prestasi akademik, hingga meningkatnya kinerja dari guru yang mengajar. Sejalan dengan tugas kepala sekolah dalam Peraturan Menteri Pendidikan dan Kebudayaan No. 6 tahun 2018 tentang manajerial, maka penulis berupaya meningkatkan kinerja guru di SDN 65 Singkawang. Hasil observasi pembelajaran yang dilaksanakan kepala sekolah, diperoleh fakta bahwa pengelolaan pembelajaran yang dilakukan oleh guru cenderung masih menggunakan pembelajaran konvensional, seperti metode ceramah, tanya jawab, pemberian tugas hingga kualitas pembelajaran masih rendah. Guru masih cenderung mengajar tanpa rencana pembelajaran dan masih menggunakan metode pembelajaran yang berpusat pada guru.Untuk mengkondisikan pembelajaran sekolah yang bermutu, maka dilakukanlah upaya meningkatkan kompetensi guru dalam menggunakan media pembelajaran berbasis IT melalui bimbingan berkelanjutan pada Guru Kelas SDN 65 Singkawang.

Istilah TI sendiri lebih merujuk pada teknologi yang digunakan dalam menyampaikan maupun mengolah informasi, namun pada dasarnya masih merupakan bagian dari sistem informasi itu sendiri. IT (Information Technology) atau TI (Teknologi Informasi) adalah bagian dari istilah dalam dunia SI (Sistem Informasi) atau IS (Information System).TI secara mudah dapat dipahami sebagai pengolahan informasi yang berbasis pada teknologi komputer dan karenanya terkait erat dengan perkembangan teknologi komputer.

Teknologi adalah cara atau metode serta proses atau produk yang dihasilkan dari pemanfaatan berbagai disiplin ilmu pengetahuan yang menghasilkan nilai bagi pemenuhan kebutuhan, kelangsungan dan peningkatan mutu kehidupan manusia [1]. Sedangkan DIKTI mendefinisikan sebagai ilmu terapan yang telah dikembangkan lebih lanjut meliputi perangkat keras (hardware) maupun perangkat lunak (software) melalui kegiatan penelitian dan pengembangan.

Kata teknologi secara harfiah berasal dari bahasa latin "texere" yang berarti menyusun atau membangun. Sehingga istilah teknologi seharusnya tidak terbatas pada penggunaan mesin, meskipun dalam arti sempit hal tersebut sering digunakan dalam kehidupan sehari-hari. Teknologi adalah suatu rancangan (desain) untuk alat bantu tindakan yang mengurangi ketidakpastian dalam hubungan sebab akibat dalam mencapai suatu hal yang diinginkan [2]. Teknologi juga diartikan sebagai keseluruhan metode yang secara rasional mengarah dan memiliki ciri efisiensi dalam setiap kegiatan manusia [3]. 
Teknologi telah dikenal manusia sejak jutaan tahun yang lalu karena dorongan untuk hidup yang lebih nyaman, lebih makmur dan lebih sejahtera [4]. Jadi sejak awal peradaban sebenarnya telah ada teknologi, meskipun istilah "teknologi" belum digunakan. Istilah "teknologi" berasal dari "techne" atau cara dan "logos" atau pengetahuan. Jadi secara harfiah teknologi dapat diartikan pengetahuan tentang cara. Pengertian teknologi sendiri menurutnya adalah cara melakukan sesuatu untuk memenuhi kebutuhan manusia dengan bantuan akal dan alat, sehingga seakan-akan memperpanjang, memperkuat atau membuat lebih ampuh anggota tubuh, pancaindra dan otak manusia.

Sedangkan informasi merupakan data yang berasal dari fakta yang tercatat dan selanjutnya dilakukan pengolahan (proses) menjadi bentuk yang berguna atau bermanfaat bagi pemakainya. Bentuk informasi yang kompleks dan terintegrasi dari hasil pengolahan sebuah database yang akan digunakan untuk proses pengambilan keputusan pada manajemen akan membentuk sistem informasi manajemen. Data merupakan fakta atau nilai (value) yang tercatat atau mempresentasikan deskripsi dari suatu objek.Data merupakan suatu sumber yang sangat berguna bagi hampir di semua organisasi.Dengan tersedianya data yang melimpah, maka masalah pengaturan data secara efektif menjadi suatu hal yang sangat penting dalam pengembangan system informasi manajemen. Pengertian Informasi, definisi informasi, pengertian data, definisi data, data dan sistem.

Jadi teknologi informasi menurut Muslim adalah suatu teknologi yang digunakan untuk mengolah data, termasuk memproses, mendapatkan, menyusun, menyimpan, memanipulasi data dalam berbagai cara untuk menghasilkan informasi yang berkualitas, yaitu informasi yang relevan, akurat dan tepat waktu, yang digunakan untuk keperluan pribadi, bisnis, dan pemerintahan dan merupakan informasi yang strategis untuk pengambilan keputusan.

Teknologi ini menggunakan seperangkat komputer untuk mengolah data, sistem jaringan untuk menghubungkan satu komputer dengan komputer yang lainnya sesuai dengan kebutuhan, dan teknologi telekomunikasi digunakan agar data dapat disebar dan diakses secara global.Arti teknologi informasi bagi dunia pendidikan seharusnya berarti tersedianya saluran atau sarana yang dapat dipakai untuk menyiarkan program pendidikan.Pemanfaatan teknologi informasi dalam bidang pendidikan sudah merupakan kelaziman.Membantu menyediakan komputer dan jaringan yang dihubungkan dengan ruang kelas, guru, dan administrator sekolah.Semuanya dihubungkan ke internet, dan para guru dilatih menggunakan komputer pribadi.

Berdasarkan perkembangan teknologi tersebut, media pembelajaran dapat dikelompokkan dalam empat jenis. Salah satu diantaranya media pembelajaran berbasis komputer. Teknologi berbasis komputer merupakan cara menghasilkan atau menyampaikan materi dengan menggunakan sumber-sumber yang berbasis mikroprosesor. Perbedaan antara media yang lain yaitu dimana informasi/ materi disimpan dalam bentuk digital, bukan dalam bentuk cetakan atau visual. Pada dasarnya teknologi berbasis komputer dalam penyajian materi kepada siswa menggunakan layar kaca. Berbagai jenis aplikasi teknologi berbasis komputer dalam pembelajaran umumnya dikenal sebagai computer-asissisted instruction (belajar dengan bantuan komputer). Aplikasi tersebut apabila dilihat dari cara penyajian dan tujuan yang ingin dicapai meliputi tutorial (penyajian materi pelajaran secara bertahap), drills and practice (latihan untuk membantu siswa mengusai materi yang telah dipelajari semuanya), permainan dan simulasi (latihan mengaplikasikan pengetahuan dan keterampilan yang baru dipelajari), dan basis data (sumber yang dapat membantu siswa menambah informasi dan pengetahuan sesuai dengan keinginan masing-masing).

Beberapa ciri media yang dihasilkan teknologi berbasis komputer (baik perangkat keras maupun perangkat lunak), sebagai berikut :Mereka dapat digunakan secara acak nonsekuen-sial, atau secara linear;Mereka dapat digunakan berdasarkan keinginan siswa atau berdasarkan keinginan perancangan/ pengembangan sebagaimana direncanakan;Biasanya gagasan-gagasan disajikan dalam gaya abstrak dengan kata, simbol, dan grafik; Prinsip-prinsip ilmu kognitif untuk mengembangkan media ini;Pembelajaran dapat melibatkan interaktif siswa lebih tinggi [5].

Kriteria pemilihan media bersumber dari konsep bahwa media merupakan bagian dari sistem instruksional secara keseluruhan, pengembangan sesuai media harus sesuai dengan tujuan yang ingin dicapai, kondisi dan keterbatasan yang ada dengan mengingat kemampuan dan sifat-sifat karakteristik media yang bersangkutan. Ada beberapa kriteria yang patut diperhatikan dalam memilih media antara lain:Sesuai dengan tujuan yang ingin dicapai;untuk mendukung isi dari pelajaran yang sifatnya fakta, konsep, prinsip/hukum, dan generalisasi; Praktis, luwes, dan bertahan; Guru terampil menggunakannya; Pengelompokan sasaran; Mutu teknis [5].

Kriteria dalam mereview perangkat lunak media pembelajaran yang berdasarkan kepada kualitas, yaitu: Kualitas isi dan tujuan meliputi ketepatan, kepentingan, kelengkapan, keseimbangan, minat/perhatian, keadilan, dan kesesuaian dengan situasi siswa; Kualitas instruksional meliputi memberikan kesempatan belajar, memberikan bantuan untuk belajar, kualitas memotivasi, flekssibilitas instruksionalnya, kualitas tes dan penilaiannya, dapat memberi dampak bagi siswa, dapat membawa dampak bagi guru dan pembelajarnya; Kualitas teknis meliputi keterbacaan, mudah digunakan, kualitastampilan/tayangan, kualitas penanganan jawaban, kualitas pengelolaan programnya, dan kualitas pendokumentasiannya [5].

Pengertian bimbingan berkelanjutan sebagai bantuan yang diberikan kepada individu untuk dapat memilih, mempersiapkan diri dan memangku suatu jabatan dan mendapat kemajuan dalam jabatan yang dipilihnya [6]. Bimbingan membantu individu untuk lebih mengenal berbagai informasi tentang dirinya sendiri [7]. 
Berdasarkan pendapat ahli [8] bahwa bimbingan dilakukan untuk meningkatkan perwujudan diri individu. Dapat dipahami bahwa bimbingan membantu individu untuk mengaktualisasikan diri dengan lingkungannya. Menurut [9] Bimbingan adalah petunjuk penjelasan cara mengerjakan sesuatu, tuntutan.

Dari beberapa pengertian bimbingan di atas, dapat ditarik kesimpulan bahwa bimbingan adalah pemberian bantuan kepada individu secara berkelanjutan dan sistematis yang dilakukan oleh seorang ahli yang telah mendapat latihan khusus untuk itu,dimaksudkan agar individu dapat memahami dirinya, lingkungannya, serta dapat mengarahkan diri dan menyesuaikan diri dengan lingkungan untuk dapat mengembangkan potensi dirinya secara optimal untuk kesejahteraan dirinya dan kesejahteraan masyarakat. Menurut Redaksi Kamus Besar Bahasa Indonesia, Edisi Kedua, "Berkelanjutan adalah berlangsung terus menerus, berkesinambungan".

Berdasarkan pengertian bimbingan dan berkelanjutan dapat ditarik suatu kesimpulan bahwa bimbingan berkelanjutan adalah pemberian bantuan yang diberikan seorang ahli kepada seseorang atau individu secara berkelanjutan berlangsung secara terus menerus untuk dapat mengembangkan potensi dirinya secara optimal dan mendapat kemajuan dalam bekerja.

Kegiatan Bimbingan berkelanjutan yang dilakukan sasaran utamanya adalah semua guru yang ada di SDN 65 Singkawang. Tujuan utamanya adalah supaya guru mampu meningkatkan keterampilan operasionalnya dalam melaksanakan pembelajaran dengan menggunakan media pembelajaran berbasis IT. Bimbingan berkelanjutan pada guru SDN 65 Singkawang dengan peningkatan penggunaan media pembelajaran berbasis IT diberikan oleh narasumber dengan prinsip - prinsip sebagai berikut: Profesional, yaitu narasumber memiliki kompetensi yang memadai dan memberikan pendampingan dengan baik,Berdasarkan kebutuhan, yaitu aspek-aspek pendampingan adalah butirbutir yang memang guru perlukan untuk meningkatkan mutu pembelajaran,Integral, yaitu aspek-aspek dan aktivitas pendampingan memfasilitasi guru dalam mengimplementasikan pembelajaran dengan media berbasis IT, Kolegial, yaitu hubungan kesejawatan antara narasumber, guru, dan kepala sekolah, berkelanjutan, yaitu bahwa pendampingan pelaksanaan pembelajaran dengan menggunakan media berbasis IT dilanjutkan oleh sekolah sendiri melalui mekanisme yang dikembangkannya.

Sedangkan inovasi pembelajaran merupakan perubahan sistem dari yang kurang baik ke arah yang lebih baik. Sedangkan pembelajaran merupakan serangkaian kegiatan yang dirancang untuk memungkinkan terjadinya proses belajar pada siswa. Implikasinya bahwa pembelajaran sebagai suatu proses yang harus dirancang, dikembangkan dan dikelola secara kreatif, dinamis, dengan menerapkan pendekatan multi untuk menciptakan suasana dan proses pembelajaran yang kondusif bagi siswa. Pembelajaran merupakan sesuatu yang kompleks, artinya segala sesuatu yang terjadi pada proses pembelajaran harus merupakan sesuatu yang sangat berarti baik ucapan, pikiran maupun tindakan.

Jadi yang dimaksud dengan inovasi pembelajaran yaitu proses belajar pada siswa yang dirancang, dikembangkan dan dikelola secara kreatif, dinamis, dengan menerapkan pendekatan multi kearah yang lebih baik, untuk menciptakan suasana dan proses pembelajaran yang kondusif bagi siswa.

Dengan adanya peningkatan kemampuan guru dalam menerapkan model pembelajaran berbasis IT melalui bimbingan berkelanjutan ini diharapkan dapat memberikan rasa senang pada siswa untuk belajar, membantu siswa untuk memahami materi yang abstrak. Pembelajaran akan menjadi lebih jelas, menarik dan lebih interaktif.

\section{METODE PENELITIAN}

Penelitian dilakukan pada guru SDN 65 Singkawang yang berjumlah 16 orang.Hasil penelitian menunjukkan bahwa $88 \%$ guru cenderung mengajar masih menggunakan pembelajaran konvensional. Untuk itu dilakukanlah IHT (In House Training) dalam bentuk Workshop SAGUSAMED yang dilaksanakan pada tanggal 27 September 2018. Untuk melihat sejauh mana keberhasilan kegiatan IHT, maka di adakan supervisi akademik. Ternyata hanya $38 \%$ guru yang menggunakan media pembelajaran berbasis IT. Kondisi ini belum cukup untuk meningkatkan mutu proses belajar mengajar. Untuk itu dilakukanlah IHT berikutnya dalam bentuk workshop Inovasi Pembelajaran pada tanggal 27 Oktober 2018. Dilanjutkan dengan pendampingan oleh kepala sekolah melalui supervisi akademik yang dilaksanakan pada bulan November 2018.

\section{HASIL DAN PEMBAHASAN}

Hasil observasi pembelajaran yang dilaksanakan kepala sekolah,terhadap 16 orang guru diperoleh fakta bahwa pengelolaan pembelajaran yang dilakukan oleh guru cenderung masih menggunakan pembelajaran konvensional, seperti metode ceramah, tanya jawab, pemberian tugas hingga kualitas pembelajaran masih rendah. Guru masih cenderung mengajar tanpa rencana pembelajaran dan masih menggunakan metode pembelajaran yang berpusat pada guru dan jarang menggunakan media termasuk media pembelajaran berbasis IT. Keadaan ini menyebabkan pembelajaran belum optimal dalam memberikan pengembangan kompetensi siswa yang ditunjukkan oleh rendahnya capaian hasil belajar siswa

Untuk menyikapi masalah ini maka diadakanlah pertemuan dengan seluruh dewan guru dan komite sekolah untuk merencanakan pelaksanaan IHT tentang cara penggunaan media pembelajaran berbasis IT. Diharapkan kegiatan ini mampu memberikan perubahan pada guru. yang pertama dilakukan adalah pemilihan narasumber. Untuk kegiatan peningkatan mutu pendidikan dengan menggunakan media pembelajaran berbasis IT perlu nara sumber yang menguasai IT dan kaya dengan pengalaman 
membuat media pembelajaran baik penyajiannya dikelas dengan menggunakan laptop dan infocus projector maupun menggunakan HP Android. Selanjutnya adalah menentukan waktu dan tempat pelaksanaan. Mengingat waktu yang agak longgar adalah dibulan September dan Oktober maka pihak sekolah dalam hal ini panitia pelaksanaan merencanakan kegiatan di bulan September yaitu tanggal27 September 2018 .

Kegiatan IHT yang pertama adalah SAGUSAMED (Satu Guru Satu Media) yang dilaksanakan pada tanggal 27 September 2018. Guru diajarkan menggunakan media pembelajaran yang sifatnya IT. Guru dilatih untuk mengajar dengan menggunakan alat peraga dengan cara membuat powerpoin, game dan lain lain. Selain itu juga untuk menjaga kemungkinan guru yang tidak menguasai IT tetap bisa menggunakan media pembelajaran, mereka dilatih untuk memanfaatkan sumber daya alam untuk kegiatan belajar mengajar misalnya memanfaatkan kearifan lokal setempat.Pada sesi kedua setiap guru tampil di depan kelas mengajar dengan menggunakan alat peraga atau media pembelajaran yang dianggap sesuai dengan materi pelajaran yang mereka ajarkan dan sesuai dengan pilihan mereka. Diharapkan di depan kelas guru mengajar selalu menggunakan alat peraga baik dengan media elektronik maupun alat peraga dengan memanfaatkan alam sekitar. Tapi guru dalam hal ini lebih dititikberatkan untuk menggunakan media pembelajaran elektronik.

Untuk melihat sejauh mana keberhasilan kegiatan IHT yang dilakukan,maka dilakukan supervisi akademik.. Tujuan supervisi kali ini adalah untuk mengetahui sampai dimana kemampuan guru dalam menggunakan media pembelajaran berbasis IT. Bentuk supervisinya adalah Kunjungan Kelas. Setelah melakukan supervisi akademik dengan metode Kunjungan Kelas,maka didapatlah data dari jumlah guru 16 orang,yang menggunakan media pembelajaran berbasis IT hanyalah $38 \%$. Tapi setiap tingkatan kelas terwakili satu orang guru yang menggunakan media pembelajaran berbasis IT.Sedangkan untuk guru yang kurang mahir dalam menggunakan IT dalam hal ini laptop,mereka menggunakan alat peraga dengan memanfaatkan benda benda yang ada di alam sekitar.

Melihat kondisi ini dimana hanya $38 \%$ guru yang menggunakan media pembelajaran berbasis IT, maka dirasakan kondisi ini belum cukup untuk meningkatkan mutu proses belajar mengajar siswa. Untuk mengupayakan supaya semua guru bisa menggunakan IT bukanlah hal yang mudah. Guru senior yang gagap IPTEK merupakan kekurangan yang tidak mudah untuk diselesaikan.Untuk itu perlu dilaksanakan IHT yang selanjutnya agar hal ini dapat teratasi ,yaitu IHT tentang Inovasi Pembelajaran.

Untuk melaksanakan kegiatan IHT yang kedua ,juga dilakukan hal yang sama seperti pada kegitan IHT yang sebelumnya yaitu diadakan pertemuan dengan seluruh dewan guru,komite sekolah untuk merencanakan pelaksanaan IHT tentang Inovasi Pembelajaran. Diharapkan kegiatan ini mampu memberikan perubahan yaitu agar guru mampu mengajar dengan menciptakan suasana mengajar yang menarik siswa,sehingga siswa fokus dan mempunyai minat yang tinggi untuk mengikuti pelajaran. Hasil rapat antara lain pembentukan panitia pelaksana, menyusun program kegiatan, dan menentukan waktu pelaksanaan yaitu tanggal 27 Oktober 2018.

Perubahan yang terjadi setelah adanya kegiatan IHT (In House Training ) tentang bimbingan berkelanjutan untuk meningkatkan kompetensi guru dalam menggunakan media pembelajaran berbasis IT dan inovasi pembelajaran adalah guru sudah mulai terbiasa menggunakan laptop dan infocus ketika mengajar. Guru yang kurang menguasai IT, sudah mulai mengubah pola mengajarnya yang dulunya bersifat konvensional, sekarang sudah mulai menerapkan inovasi dalam pembelajaran.Setiap memulai dan mengakhiri pembelajaran menyanyikan lagu wajib atau lagu daerah atau menggunakan yel yel untuk memotivasi siswa agar lebih semangat dalam belajar. Prestasi yang pertama didapat adalah juara 1 lomba Olimpiade Siswa Nasional (OSN) se kota Singkawang untuk Matematika dengan capaian nilai 72. Untuk hasil nilai Try Out tahun ini, yang dulunya SDN 65 Singkawang berada di ranking terbawah sekecamatan Singkawang Timur, sekarang sudah bisa memperbaiki posisi di ranking 9. Perubahan ini cukup membanggakan untuk pihak sekolah,karena dengan adanya IHT ini,sekolah mampu meraih prestasi yang tidak diduga sebelumnya.

\section{KESIMPULAN}

Dari kegiatan IHT tentang penggunaan media pembelajaran berbasis IT dapat disimpulkan bahwa pelaksanaan IHT membuat perubahan pada gaya mengajar guru yang awalnya menggunakan pembelajaran konvensional,setelah adanya kegiatan bimbingan berkelanjutan ini, sebagian guru sudah menggunakan media pembelajaran berbasis IT dan melakukan inovasi-inovasi dalam pembelajaran. Pelaksanaan kegiatan IHT yang dilaksanakan di sekolah sendiri, menumbuhkan rasa percaya diri pada kepala sekolah, guru dan seluruh stakeholder yang ada di sekolah untuk maju sendiri tanpa harus menunggu bantuan atau uluran tangan dari pihak lain. Dampak positif lainnya, siswa menjadi terbiasa tampil presentase di depan kelas. Hal ini juga berdampak pada kegiatan ekstrakulikuler. Pada tahun sebelumnya SDN 65 tidak ada sama sekali meraih piala untuk lomba O2SN dan FLS2N. Untuk 2019 ini SDN 65 Singkawang mampu meraih juara I lomba Atletik putra, juara 2 lomba Tari Kreasi dan juara 2 lomba Senam PGRI,di tingkat kecamatan dan juara 3 atletik putra tingkat kota.

Untuk dapat meningkatkan mutu pendidikan dengan menggunakan media pembelajaran berbasis IT melalui bimbingan berkelanjutan pada guru kelas di SDN 65 Singkawang,maka disarankan kepadapendidikagar senantiasa membimbing peserta didik dalam kegiatan proses belajar mengajar dengan meningkatkan potensi diri.Selalu memberikan dukungan terhadap pelaksanaan program sekolah dan dapat memanfaatkan peluang yang ada untuk meningkatkan kemampuan profesional sebagai pendidik. 
Bagi kepala sekolah diharapkan selalu melakukan monitoring dan evaluasi pelaksanaan kegiatan program bimbingan berkelanjutan untuk mengetahui kekurangan dan kelebihan agar dapat merencanakan tindakan selanjutnya. Terus melaksanakan perubahan dengan melanjutkan program bimbingan berkelanjutan pada guru dan menyiapkan sarana prasarana yang diperlukan.

\section{DAFTAR PUSTAKA}

[1] Depdiknas. (2002). Undang-undang RI Nomor 12. Jakarta: Depdiknas.

[2] Everett M. Rogers. (1983). Diffusion of Innovation. London: The Free Press.

[3] Ellul, Jaques. (1967). The Tacnological Society (terjemahan dari bahasa Prancis). New York: Alfred A. Knopf.

[4] Alisyahbana, Iskandar. (1980). Teknologi dan Perkembangan. Jakarta: Yayasan Idayu.

[5] Arsyad, Azhar. (2011). Media Pembelajaran. Jakarta: PT Raja Grafindo Persada.

[6] Parsons, T. (1951). The Social System. New York: The Free Press.

[7] Fatihah, RM. (2008). Pengertian Konseling (http://eko13.wordpress.com, diakses 20 Agustus 2019).

[8] Bernard, H.W., \& Fullme, D.W. (1969). Principle of Guidance. New York: Harver \& Row Publishers.

[9] Departemen Pendidikan Indonesia. (2008). Kamus Besar Bahasa Indonesia. Jakarta: Balai Pustaka. 